\title{
MAPPING KEBUTUHAN PENGEMBANGAN KOMPETENSI GURU PAI SD DI SUKOHARJO: SEBAGAI PIJAKAN DALAM MENDESAIN PROGRAM PENGABDIAN DOSEN PAI
}

\author{
Fauzi Muharom \\ Institut Agama Islam Negeri (IAIN) Surakarta \\ fauzimubarom@yaboo.com
}

\begin{abstract}
This research aimed at knowing the mapping of the needs of teacher competence development of Islamic Education teachers of the Elementary Schools in 12 districts in Sukoharjo. The data were collected through interview and documentation. The results of the research showed that the mapping of the needs of teacher competence development of the Islamic Education teachers of the Elementary Schools is learning strategies, training of classroom action research, qur'an recitation assisting, training of making learning media, training of information technology learning, training of making test item grids, training of making teaching materials, assisting of curriculum 2013, training of making teaching lesson plan, training of making administration for Islamic Education teachers, training of graphic art, training of the art of Islamic Javanese song macapat and rebana. The design of the lecturer community service for the lecturers of Islamic Education Department of IAIN Surakarta can be conducted in two kinds of designs namely focusing on the needs of teacher competence development of the Islamic Education of the Elementary Schools in one district, based on the priority scales of teacher competence development of Islamic Education of the Elementary Schools in Sukoharjo.
\end{abstract}

Keywords: Lecturer Community Service, Teacher Competence, Teacher Work Group

\begin{abstract}
Abstrak
Penelitian ini bertujuan untuk mengetabui pemetaan kebutuban pengembangan kompetensi guru PAI SD di dua belas Kecamatan di Kabupaten Sukoharjo. Data dalam penelitian ini dikumpulan melalui wawancara dan dokumentasi. Hasil penelitian ini menunjukkan bahwa pemetaan kebutuban pengembangan kompetensi guru PAI SD di Kabupaten Sukoharjo yakni pelatihan strategi/metode pembelajaran, pelatihan penyusunan PTK, bimbingan bacaan al-Qur'an, pelatihan pembuatan media pembelajaran, pelatihan pembelajaran IT/TIK, pelatihan pembuatan kisikisi dan soal ulangan, pelatihan pembuatan bahan ajar, bintek kurikulum 2013, pelatihan pembuatan perangkat pembelajaran, pelatiban pembuatan administrasi guru PAI, pelatihan seni grafi, pelatihan seni macapat islami dan rebana. Sedangkan desain program pengabdian dosen Jurusan PAI IAIN Surakarta bisa dilakukan dalam dua desain yakni fokus pada kebutuhan pengembangan kompetensi guru PAI SD di satu kecamatan dan sesuai urutan prioritas kebutuban pengembangan kompetensi guru PAI SD di Kab.Sukoharjo.
\end{abstract}

Kata Kunci: Pengabdian Dosen, Kompetensi Guru, Kelompok Kerja Guru

Permalink/DOI: http://dx.doi.org/10.18326/infs13.v9i2.491-514 


\section{Pendahuluan}

Pendidikan merupakan suatu kebutuhan dasar yang diperlukan oleh setiap manusia. Karena pendidikan merupakan tindakan sadar dengan tujuan memelihara dan mengembangkan fitrah serta potensi (sumber daya) insani menuju terbentuknya manusia seutuhnya (insan kamil). (Achmadi, 1992: 16) Melalui media pendidikan maka manusia akan mempunyai ilmu dan manusia yang mempunyai ilmu akan dinaikkan derajatnya oleh Tuhan Yang Maha Pemberi Ilmu. Berdasarkan hal ini nampaklah bahwa antara pendidikan dan manusia mempunyai hubungan yang sangat erat.

Secara filosofis manusia merupakan subyek sekaligus obyek dalam pendidikan. Manusia memikul tanggung jawab ganda, baik sebagai penyelenggara pendidikan sekaligus sebagai penerima pendidikan. Eksistensi manusia dapat menempati posisi manusia dewasa yang berbudaya dan manusia yang belum dewasa. Manusia dewasa yang berbudaya adalah subyek pendidikan dalam arti bertanggung jawab menyelenggarakan pendidikan dan berkewajiban secara moral atas perkembangan pribadi anakanak. Sedangkan bagi manusia yang belum dewasa dalam proses perkembangan kepribadiannya, baik menuju pembudayaan proses kematangan maupun integritas adalah obyek dalam pendidikan. (Noorsyam, 1986: 153).

Sosok guru merupakan subyek dalam pendidikan dan menjadi salah satu faktor penentu keberhasilan dalam dunia pendidikan. Karena guru merupakan pemegang peranan sentral sekaligus sebagai sumber kegiatan belajar mengajar. (Aqib, 2002:22) Untuk itu seorang guru harus memiliki kemampuan dan kualitas yang baik dalam mengelola pembelajaran kepada peserta didik. Guru wajib memiliki kualifikasi akademik, kompetensi, sertifikat pendidik, sehat jasmani dan rohani, serta memiliki kemampuan untuk mewujudkan tujuan pendidikan nasional. (UU RI No. 14 tahun 2005) Apabila guru tidak dapat memberikan proses pendidikan yang berkualitas, maka tujuan pendidikan tidak akan tercapai dengan baik juga.

Masalah-masalah tentang rendahnya kualitas dan kompetensi guru masih menjadi permasalahan yang belum teratasi dengan baik sampai sekarang. (Hidayah dan Tairas, 2013: 2) Problem-problem 
rendahnya kualitas dan kompetensi guru di atas telah menjadi perhatian oleh pemerintah. Pemerintah telah berusaha memberikan solusi-solusi terhadap problem-problem ini. Sebagai bukti adalah pemerintah telah menerbitkan beberapa kebijakan ataupun undangundang yang berhubungan dengan peningkatan kompetensi atau kualitas guru. Salah satunya adalah UU No. 14 Tahun 2005 pasal 7 mengamanatkan bahwa pemberdayaan profesi guru diselenggarakan melalui pengembangan diri yang dilakukan secara demokratis, berkeadilan, tidak diskriminatif, dan berkelanjutan dengan menjunjung tinggi hak asasi manusia, nilai keagamaan, nilai kultural, kemajemukan bangsa, dan kode etik profesi.

Harapan pemerintah dalam meningkatkan kualitas dan kompetensi guru ini harus didukung oleh para guru itu sendiri, kepala sekolah/madrasah, dan juga lembaga pendidikan di atasnya yakni perguruan tinggi. Berdasarkan pernyataan ini berarti para guru harus sadar tentang peningkatan kompetensi dirinya, dan kepala sekolah/madrasah bisa berperan juga dalam memfasilitasi peningkatan kompetensi gurunya serta didukung oleh pihak kampus/perguruan tinggi dalam memberikan pelatihan atau tutorial dalam peningkatan kompetensi guru.

Partisipasi perguruan tinggi dalam dalam memberikan pelatihan atau tutorial kepada para guru dalam operasionalnya dilakukan oleh para dosen. Dalam hal ini para dosen melakukan program pengabdian kepada masyarakat. Kegiatan dosen dalam melakukan program pengabdian kepada masyarakat ini berarti dosen telah melakukan salah satu kewajiban yang telah diamanahkan dalam Tri Darma Perguruan Tinggi.

Kewajiban para dosen dalam melakukan pengabdian kepada masyarakat ini idealnya dilakukan oleh setiap lembaga pendidikan tinggi, termasuk di dalamnya IAIN Surakarta. Menurut Ketua Jurusan Pendidikan Agama Islam (PAI), kegiatan pengabdian kepada masyarakat yang legal formal atas nama jurusan baru tahun kemarin dilakukan. Pada saat itu, pihak jurusan langsung mengadakan pengabdian dengan melibatkan beberapa dosen dengan mendatangkan peserta para guru yang mengajar di madrasah. 
Melihat pernyataan ini maka dibutuhkan desain pengabdian untuk kegiatan mendatang dengan berbasis usulan dan masukan dari para guru, khususnya guru PAI yang ada di kabupaten Sukoharjo. Di sinilah muncul kegelisahan akademik untuk melakukan mapping kebutuhan pengembangan atau peningkatan kompetensi guru PAI SD yang ada di dua belas kecamatan di Kabupaten Sukoharjo melalui Kelompok Kerja Guru (KKG) PAI SD. Hasil dari pemetaan kebutuhan inilah yang akan digunakan sebagai pijakan membuat desain pengabdian dosen Jurusan PAI Fakultas Ilmu Tarbiyah dan Keguruan IAIN Surakarta.

\section{Pengabdian Dosen}

Dalam Undang-undang Republik Indonesia Nomor 14 tahun 2005 tentang Guru dan Dosen, pasal 1, dikatakan bahwa dosen adalah pendidik profesional dan ilmuwan dengan tugas utama mentransformasikan, mengembangkan, dan menyebarluaskan ilmu pengetahuan, teknologi, dan seni melalui pendidikan, penelitian, dan pengabdian kepada masyarakat. Regulasi ini memberikan penekanan pada profesi dosen bukan hanya merupakan seorang pendidik professional pada perguruan tinggi, melainkan secara bersamaan dosen juga seorang ilmuwan dan pelopor dalam pengabdian pada masyarakat. (Arwildayanto, 2012: 15).

Nampaklah bahwa pengabdian kepada masyarakat oleh dosen merupakan salah satu pilar tri dharma perguruan tinggi, sehingga tidak salah jika dalam instrumen beban kerja dosen aspek pengabdian merupakan unsur yang diperhitungkan. Menurut buku Pedoman BKD dan Evaluasi Pelaksanaan Tridharma Perguruan Tinggi yang dikeluarkan Direktorat Jenderal Pendidikan Tinggi Tahun 2010, diuraikan bahwa tugas dosen dalam melakukan pengabdian kepada masyarakat dapat berupa (1) menduduki jabatan pimpinan dalam lembaga pemerintahan/pejabat negara sehingga harus dibebaskan dari jabatan organiknya; (2) melaksanakan pengembangan hasil pendidikan dan penelitian yang dapat dimanfaatkan oleh masyarakat; (3) memberi latihan/penyuluhan/ penataran pada masyarakat; (4) memberi pelayanan kepada masyarakat atau kegiatan lain yang menunjang pelaksanaan tugas 
umum pemerintah dan pembangunan; (5) membuat/menulis karya pengabdian kepada masyarakat.

\section{Kompetensi Guru PAI}

Pengertian kompetensi berasal dari bahasa Inggris 'competence', yang artinya kemampuan atau kecakapan (Muhibbin, 2000: 229). Kompetensi berarti suatu hal yang menggambarkan kualifikasi atau kemampuan seseorang baik kuantitatif maupun kualitatif. (Usman, 2001: 4) Ada juga yang mengartikan bahwa kompetensi adalah penguasaan terhadap suatu tugas, ketrampilan, sikap, dan apresiasi yang diperlukan untuk menunjang keberhasilan. (Mulyasa, 2004: 38)

Kompetensi jika dikaitkan dengan guru, maka arti dari kompetensi guru adalah kemampuan seorang guru dalam melaksanakan kewajiban-kewajiban secara bertanggung jawab dan layak (Rusman, 2013: 70). Bisa juga diartikan sebagai pembulatan pengetahuan, keterampilan dan sikap yang berwujud tindakan cerdas dan penuh tanggung jawab dalam melaksanakan tugas sebagai agen pembelajaran. (Sarimaya, 2008: 17)

Masalah kompetensi yang harus dimiliki seorang guru, ternyata pemerintah sangat concern dalam masalah ini. Item kompetensi telah dimasukkan oleh pemerintah dalam PP No. 74 tahun 2008. (Musfah, 2012: 30) Kompetensi dalam PP No. 74 tahun 2008 diartikan sebagai seperangkat pengetahuan, keterampilan,dan perilaku yang harus dimiliki, dihayati, dikuasai, dan diaktualisasikan oleh guru dalam melaksanakan tugas keprofesionalan. Kompetensi guru dalam hal ini meliputi kompetensi pedagogik, kompetensi kepribadian, kompetensi sosial, dan kompetensi professional. Empat kompetensi ini selaras dengan tugas dan tanggung jawab serta wewenang dari guru PAI untuk meningkatkan kualitas peserta didik dalam bidang Pendidikan Agama Islam yang meliputi tujuh unsur pokok yaitu: keimanan, ketakwaan, ibadah, al-Qur'an, syariah, muamalah, dan akhlak. (Ardy, 2012: 99) 


\section{Kelompok Kerja Guru (KKG)}

Kelompok Kerja Guru (KKG) adalah suatu wadah guru sekolah dasar untuk membahas masalah-masalah yang dihadapi guru dalam melaksanakan proses pembelajaran. (Tabrani, 2000: 39) Wadah ini tergabung dalam organisasi gugus sekolah yang bertujuan menjadikan guru lebih berkualitas dalam upaya meningkatkan pendidikan Sekolah Dasar melalui pendekatan sistem pembinaan profesional dan kegiatan belajar mengajar aktif. Di dalam wadah ini para guru dapat membahas permasalahan dari mereka dan untuk mereka. (Wahyudin, 1995: 10) Sedangkan pengertian dari KKG PAI SD adalah organisasi pembinaan profesi Guru Pendidikan Agama Islam pada SD dan SDLB. (Permenag No. 16 Tahun 2010 )

\section{Metode Penelitian}

Penelitian ini merupakan penelitian kualitatif yang bersifat deskriptif. Penelitian kualitatif merupakan penelitian yang dilakukan secara langsung dengan data yang diperoleh diuraikan dalam bentuk katakata (Margono, 2009: 122). Hal ini didasarkan kepada rumusan masalah penelitian yang menuntut peneliti untuk mengkaji masalah yang diteliti melalui hubungan yang intensif dengan sumber data.

Metode yang digunakan untuk mengumpulkan data dalam penelitian ini adalah wawancara dan dokumentasi. Wawancara lebih fokus kepada pengurus KKG PAI SD di dua belas Kecamatan. Data-data kebutuhan pengembangan kompetensi guru PAI SD di dua belas kecamatan di Kabupaten Sukoharjo dapat diambil dari para pengurus KKG PAI SD di tiap Kecamatan.

Model analisis yang digunakan dalam penelitian ini adalah model interaktif (interactive model of analysis). Artinya, ketiga komponen dalam kegiatan penelitian berjalan bersama-sama, yakni data reduction (reduksi data), data display (penyajian data) dan conclusions drawing and verifying (penarikan kesimpulan dan verifikasi). (Miles dan Hubermen, 1992: 59-60) 


\section{Analisis}

Pemetaan Kebutuhan Pengembangan Kompetensi Guru PAI SD

Untuk menghasilkan data tentang kebutuhan pengembangan kompetensi Guru PAI SD di dua belas kecamatan di Kabupaten Sukoharjo maka data diambil dari pengurus KKG PAI SD di dua belas kecamatan. Untuk lebih jelasnya dapat diuraikan di bawah ini:

1. KKG PAI SD di Kecamatan Kartasura

Kebutuhan pengembangan kompetensi Guru PAI SD di Kecamatan Kartasura antara lain:

a. Pelatihan pembelajaran berbasis IT, Kebutuhan adanya pelatihan ini adalah karena pembelajaran menggunakan IT lebih menarik minat belajar siswa.

b. Pelatihan penyusunan PTK, Pertimbangan kebutuhan adanya pelatihan ini adalah sebagai persiapan untuk kenaikan pangkat dan memotivasi guru untuk mengevaluasi kegiatan belajar mengajar yang telah dilaksanakan.

c. Pelatihan pembuatan bahan ajar, Kebutuhan adanya pelatihan ini adalah untuk memotivasi guru untuk lebih meningkatkan kemampuan menulis dan mampu menyusun bahan ajar.

Sedangkan kegiatan-kegiatan yang pernah dilakukan di KKG PAI SD kecamatan Kartasura untuk memberikan bekal bagi guru-guru PAI SD di Kecamatan Kartasura adalah pertemuan rutin satu bulan dua kali, pelatihan kurikulum 2013, workshop penyusunan naskah UTS dan UAS, Lomba MAPSI, penyusunan dan penilaian angka kredit.

2. KKG PAI SD di Kecamatan Grogol

Kebutuhan pengembangan kompetensi Guru PAI SD di Kecamatan Grogol antara lain:

a. Pembuatan alat peraga / media pembelajaran, kebutuhan adanya pembuatan alat peraga / media pembelajaran dikarenakan dalam proses pembelajaran yang menarik harus didukung dengan media yang menarik juga. Sementara 
masih banyak GPAI yang masih belum menguasai dalam pembuatan alat peraga / media pembelajaran ini.

b. Pembuatan PenelitianTindakan Kelas (PTK), kebutuhan adanya pembuatan PenelitianTindakan Kelas (PTK) adalah karena masih lemahnya kemampuan GPAI dalam pembuatan karya ilmiah khususnya PTK.

Sedangkan kegiatan-kegiatan yang pernah dilakukan di KKG PAI SD Kecamatan Grogol untuk memberikan bekal bagi guruguru PAI SD di Kecamatan Grogol adalah sosialisasi kurikulum 13, pelatihan pembelajaran berbasis komputer, pembuatan administrasi pembelajaran, mengikutsertakan anggota dalam pelatihan yang diselenggarakan oleh dinas/kemenag.

3. KKG PAI SD di Kecamatan Weru

Kebutuhan pengembangan kompetensi Guru PAI SD di Kecamatan Weru antara lain:

a. Pelatihan pembuatan PTK bagi semua guru PAI maupun Karya Tulis Ilmiah ( KTI ).Kebutuhan adanya pelatihan ini adalah adanya alasan banyak guru yang mengalami kesulitan ketika akan memenuhi angka kredit guna kenaikan pangkat.

b. Pelatihan pembuatan Prota, Promes, Silabus, RPP dan program Evaluasi. Kebutuhan adanya pelatihan ini adalah adanya alasan masih banyak guru yang belum faham betul cara pembuatan adminitrasi pembelajaran yang sangat di butuhkan para guru pai

c. Pelatihan pembuatan alat peraga sederhana untuk pembelajaran yang aktif/ efektif. Kebutuhan adanya pelatihan ini adalah karena banyak guru PAI yang masih saja menggunakan metode konvensional dalam pembelajaran sehingga anak didik kurang semangat dalam belajar dan akhirnya nilai prestasi semakin menurun.

Sedangkan kegiatan-kegiatan yang pernah dilakukan di KKG PAI SD Kecamatan Weru untuk memberikan bekal bagi guru-guru PAI SD di kecamatan Weru adalah sosialisasi hasil 
seminar, diklat maupun workshop kepada semua guru PAI SD, workshop kurikulum 2013 dengan mengundang beberapa nara sumber, pelatihan bersama membuat kisi-kisi, naskah soal sampai kunci jawaban, serta pelatihan bersama dalam berbagai macam lomba MAPSI.

4. KKG PAI SD di Kecamatan Baki

Kebutuhan pengembangan kompetensi Guru PAI SD di Kecamatan Baki antara lain:

a. Bintek Kurikulum 2013, Kegiatan ini sebenarnya sudah pernah diadakan tetapi waktunya hanya sebentar sehingga kurang matang terutama dalam hal penilaian. Untuk itu perlu diadakan pelatihan lagi yang berkaitan dengan kurikulum 2013.

b. Workshop TIK, Alasan adanya kebutuhan workshop TIK adalah karena penguasaan TIK sangatlah dibutuhkan oleh GPAI dalam mendukung proses Pembelajaran PAI

c. Workshop Model Pembelajaran, Alasan perlunya kegiatan ini adalah untuk menciptakan proses pembelajaran PAI yang bervariasi dan tidak terkesan monoton.

Sedangkan kegiatan-kegiatan yang pernah dilakukan di KKG PAI SD Kecamatan Baki untuk memberikan bekal bagi guruguru PAI SD di kecamatan Baki adalah study banding, mengikuti bintek, dan lain-lain.

5. KKG PAI SD di Kecamatan Bendosari

Kebutuhan pengembangan kompetensi Guru PAI SD di Kecamatan Bendosari antara lain:

a. Pelatihan Seni Tilawah Al Quran, Alasan perlunya kegiatan pelatihan ini adalah belum ada guru PAI yang potensial dan profesional di bidang Tilawah.

b. Pelatihan Seni Kaigrafi, Alasan perlunya kegiatan pelatihan ini adalah belum ada guru PAI yang potensial dan profesional di bidang seni kaligrafi 
c. Pelatihan Metodologi Mengajar PAI, Alasan perlunya kegiatan pelatihan ini adalah masih banyak guru PAI yang mengajarnya dengan metode konvensional. Sehingga perlu adanya pelatihan pembelajaran active learning dan menyenangkan.

Sedangkan kegiatan-kegiatan yang pernah dilakukan di KKG PAI SD Kecamatan Bendosari untuk memberikan bekal bagi guru-guru PAI SD di Kecamatan Bendosari adalah desiminasi kurikulum 2013, pertemuan rutin seminggu sekali, lomba MAPSI, pentas PAI, pembinaan-pembinaan lomba, dan lainlain.

6. KKG PAI SD di Kecamatan Polokarto

Kebutuhan pengembangan kompetensi Guru PAI SD di Kecamatan Bendosari antara lain:

a. Worshop strategi pembelajaran. Kebutuhan workshop ini dengan pertimbangan karena masih banyaknya guru PAI yang belum paham strategi pembelajaran yang variatif.

b. Pembuatan alat peragaan dan media. Pembelajaran yang baik perlu didukung adanya media atau alat peragaan, sehingga hal ini sangat dibutuhkan guru-guru PAI.

c. Pembuatan kisi-kisi dan soal ulangan (UTS/UAS/UKK) Kegiatan ini sangat berguna untuk guru PAI supaya ada keseragaman dan kesepahaman dalam pembuatan kisi-kisi dan soal ulangan.

7. KKG PAI SD di Kecamatan Gatak

Kebutuhan pengembangan kompetensi Guru PAI SD di Kecamatan Gatak antara lain:

a. Workshop peningkatan kompetensi guru dalam pengajaran. Alasan kebutuhan kegiatan ini adalah karena masih banyak guru yang dalam mengajarnya masih monoton.

b. Pelatihan Pembuatan Administrasi GPAI. Alasan kebutuhan kegiatan ini adalah karena masih banyak guru yang kurang mempehatikan administrasi GPAI 
8. KKG PAI SD di Kecamatan Tawangsari

Kebutuhan pengembangan kompetensi Guru PAI SD di Kecamatan Gatak antara lain:

a. Pelatihan Seni Macapat Islami dan reban. Kebutuhan ini dimuncukan karena adanya kenyataan bahwa belum ada guru PAI yang mahir di bidang ini.

b. Pelatihan Tilawah. Kebutuhan ini dimuncukan karena adanya kenyataan bahwa masih ada guru PAI yang belum fasih dalam tilawah.

9. KKG PAI SD di Kecamatan Bulu

Kebutuhan pengembangan kompetensi Guru PAI SD di Kecamatan Gatak antara lain:

a. Pembimbingan Tilawah. Kegiatan ini dibutuhkan karena selama ini rata rata guru PAI di Kecamatan Bulu hanya bisa murotal.

b. Pelatihan cara mengajar yang efektif bagi GPAI. Alasan adanya kegiatan ini adalah agar dapat melatih GPAI dalam mengajar materi PAI yang bervariasi dan tidak membosankan.

Sedangkan kegiatan-kegiatan yang pernah dilakukan di KKG PAI SD Kecamatan Bulu untuk memberikan bekal bagi guruguru PAI SD di Kecamatan Bulu antara lain diklat kurikulum 13, diklat pembuatan PTK, diklat rebana dan diklat,mocopat islami.

10. KKG PAI SD di Kecamatan Mojolaban

Kebutuhan pengembangan kompetensi Guru PAI SD di Kecamatan Mojolaban antara lain:

a. Workshop penyusunan PTK. Kebutuhan workshop penyusunan PTK ini dikarenakan masih banyak guru PAI SD yang belum bisa menyusun proposal dan laporan PTK.

b. Workshop pembuatan kisi-kisi dan soal ulangan. Alasan kegiatan ini adalah untuk mendukung para guru PAI SD dalam proses pembuatan kisi-kisi dan soal ulangan. 
Sedangkan kegiatan-kegiatan yang pernah dilakukan di KKG PAI SD Kecamatan Mojolaban untuk memberikan bekal bagi guru-guru PAI SD di Kecamatan Mojolaban antara lain kegiatan rutin tiap minggu, sosialisasi kurikulum 2013, dan lain-lain.

11. KKG PAI SD di Kecamatan Sukoharjo

Kebutuhan pengembangan kompetensi Guru PAI SD di Kecamatan Sukoharjo antara lain:

a. Pelatihan dan bimbingan qiro'ah dan tilawah Al-Quran. Alasan kebutuhan ini adalah masih banyak guru PAI SD yang belum memhami dan menguasai hal itu. Makanya hal ini perlu disampaikan ke mereka.

b. Kegiatan Workshop IT. Workshop ini sangat dibutuhkan karena masih banyak guru yang belum mahir mengaplikasikan program-program computer.

c. Pelatihan penyusunan PTK. Alasan kebutuhan adanya pelatihan PTK ini adalah sebagai persiapan untuk kenaikan pangkat sebagai bagian dari karir guru.

Sedangkan kegiatan-kegiatan yang pernah dilakukan di KKG PAI SD Kecamatan Sukoharjo untuk memberikan bekal bagi guru-guru PAI SD di Kecamatan Sukoharjo antara lain diklat KK 2013, work shop musik rebana, mocopat islami dan tehnik menulis arab, KKG rutin tiap hari Sabtu dan lain-lain.

\section{KKG PAI SD di Kecamatan Nguter}

Kebutuhan pengembangan kompetensi Guru PAI SD di Kecamatan Nguter adalah merancang metode pembelajaran yang efisien dan tepat sasaran. Alasan adanya kebutuhan ini adalah masih adanya para guru PAI SD yang dalam pengajaran masih terkesan menjemuhkan bagi peserta didik sehingga daya tangkap dan pemahaman peserta didik kurang maksimal. Untuk ini diperlukan pelatihan merancang metode pembelajaran yang efisien dan tepat sasaran. Atau yang biasa dinamakan pembelajaran PAIKEM.

Sedangkan kegiatan yang pernah dilakukan di KKG PAI SD Kecamatan Nguter untuk meningkatkan kompetensi guru-guru 
PAI SD di kecamatan Nguter adalah dengan mengkoordinasi guru-guru yang ada yakni mengadakan bimbingan sejawat seperti pelatihan komputer. Dalam hal ini, guru PAI SD yang menguasai IT menjadi narasumber dan menjadi pembimbing sesama guru.

\section{Desain Program Pengabdian Dosen Jurusan PAI FITK IAIN Surakarta dalam Perspektif Guru PAI SD di Sukoharjo}

Jalinan kerjasama antara pihak Jurusan PAI Fakultas Ilmu Tarbiyah dan Keguruan IAIN Surakarta dengan para guru PAI SD di Sukoharjo perlu diadakan, karena selama ini belum ada kerjasama di antara keduanya. Hal ini sesuai kenyataan bahwa Jurusan PAI Fakultas Ilmu Tarbiyah dan Keguruan IAIN Surakarta lebih sering melakukan kerjasama dengan pihak madrasah, seperti dalam urusan PPL mahasiswa. Padahal jika dirunut kompetensinya, jurusan PAI idealnya mengajar materi PAI di sekolah-sekolah.

Untuk mengawali peluang kerjasama ini, maka desain program pengabdian dosen Jurusan PAI Fakultas Ilmu Tarbiyah dan Keguruan IAIN Surakarta perlu dibuat dengan mendasarkan kepada pemetaan pemetaan kebutuhan peningkatan kompetensi guru-guru PAI SD di Kabupaten Sukoharjo. Berdasarkan pemetaan kebutuhan peningkatan kompetensi guru-guru PAI SD di Kabupaten Sukoharjo melalui kepengurusan KKG PAI SD, maka desain pengabdian dosen Jurusan PAI Fakultas Ilmu Tarbiyah dan Keguruan IAIN Surakarta bisa dilakukan dengan desain yakni:

1. Desain pengabdian dosen Jurusan PAI dilakukan dengan fokus pada kebutuhan guru PAI SD di kecamatan.

Desain ini berarti jurusan PAI Fakultas Ilmu Tarbiyah dan Keguruan IAIN Surakarta mengambil kebijakan untuk memilih KKG PAI SD yang akan diberi pendampingan/pelatihan sesuai kebutuhan dari KKG PAI SD tersebut. Sebagai contoh adalah untuk pengabdian dosen jurusan PAI difokuskan dulu untuk guru-guru PAI SD di kecamatan Kartasura melalui KKG PAI SD. Salah satu alasan mungkin karena dekat dengan kampus. Hal ini berarti pengabdian dosen jurusan PAI akan berkenaan dengan 
pelatihan pembelajaran berbasis IT, pelatihan penyusunan PTK dan pelatihan pembuatan bahan ajar. Setelah selesai bisa dilanjutkan ke KKG PAI SD di kecamatan lain disesuaikan dengan waktu dan kemampuan dari jurusan PAI.

Sebagai contoh, setelah dari kecamatan Kartasura dilanjutkan ke KKG PAI SD di kecamatan Gatak. Hal ini berarti pengabdian dari dosen jurusan PAI akan berkaitan dengan pelatihan/workshop tentang peningkatan kompetensi guru dalam pengajaran dan pembuatan administrasi GPAI. Dari Kecamatan Gatak dilanjutkan dengan kecamatan lainnya dan seterusnya. Untuk mempermudah gambaran kebutuhan kompetensi guru-guru PAI SD di tiap-tiap kecamatan dapat dilihat seperti di bawah ini:

\section{Tabel 1:}

\section{Jenis Pelatihan/Pendampingan Berdasarkan Kebutuhan GPAI SD Di Tiap Kecamatan}

\section{No $\begin{gathered}\text { Nama } \\ \text { Lembaga }\end{gathered}$ Jenis Pelatihan/pendampingan}

1. KKG PAI SD di

Kec. Kartasura

KKG PAI SD di

2.

Kec. Grogol a. Pelatihan pembelajaran berbasis IT

b. Pelatihan penyusunan PTK

c. Pelatihan pembuatan bahan ajar

a. Pembuatan alat peraga / media pembelajaran

b. Pembuatan PenelitianTindakan Kelas (PTK)

a. Pelatihan pembuatan PTK bagi semua guru PAI maupun Karya Tulis Ilmiah (KTI).

KKG PAI SD di Kec. Weru b. Pelatihan pembuatan Prota, Promes, Silabus, RPP dan program Evaluasi.

c. Pelatihan pembuatan alat peraga sederhana untuk pembelajaran yang aktif/ efektif . 

4. KKG PAI SD di
Kec. Baki

5. KKG PAI SD di Kec. Bendosari

KKG PAI SD di

6. Kec. Polokarto

KKG PAI SD

7. di Kecamatan Gatak

\section{KKG PAI}

8. SD di Kec.

Tawangsari

9. KKG PAI SD di Kec. Bulu

10. KKG PAI SD di Kec.Mojolaban

KKG PAI SD di

11. Kec.Sukoharjo

12. KKG PAI SD di Kec. Nguter a. Bintek Kurikulum 2013

b. Workshop TIK

c. Workshop Model Pembelajaran

a. Pelatihan Seni Tilawah Al Quran.

b. Pelatihan Seni Kaigrafi

c. Pelatihan Metodologi Mengajar PAI

a. Worshop strategi pembelajaran.

b. Pembuatan alat peragaan dan media.

c. Pembuatan kisi-kisi dan soal ulangan (UTS/UAS/UKK

a. Workshop peningkatan kompetensi guru dalam pengajaran

b. Pelatihan Pembuatan Administrasi GPAI

a. Pelatihan Seni Macapat Islami dan reban

b. Pelatihan Tilawah

a. Pembimbingan Tilawah

b. Pelatihan cara mengajar yang efektif bagi GPAI

a. Workshop penyusunan PTK

b. Workshop pembuatan kisi-kisi dan soal ulangan

a. Pelatihan dan bimbingan qiro'ah dan tilawah AlQuran.

b. Kegiatan Workshop IT

c. Pelatihan penyusunan PTK

Pelatihan merancang metode pembelajaran yang efisien dan tepat sasaran 
2. Desain Pengabdian Dosen Jurusan PAI sesuai Urutan Prioritas Kebutuhan Pengembangan Kompetensi Guru PAI SD di Kabupaten Sukoharjo

Desain ini berarti jurusan PAI Fakultas Ilmu Tarbiyah dan Keguruan IAIN Surakarta mengambil kebijakan untuk memilih jenis pelatihan/pendampingan sesuai urutan kebutuhan sebagimana yang telah disampaikan KKG PAI SD di tiap-tiap kecamatan. Urutan prioritas program kegiatan peningkatan kompetensi GPAI dapat dilihat seperti di bawah ini:

a. Program pelatihan strategi/metode pembelajaran. Program ini menempati urutan nomor satu berdasarkan dari pemetaan kebutuhan peningkatan kompetensi guru PAI SD di Kabupaten Sukoharjo. Program ini dibutuhkan oleh tujuh KKG PAI SD yakni KKG PAI SD Kecamatan Nguter, KKG PAI SD Kecamatan Gatak, KKG PAI SD Kecamatan Bulu, KKG PAI SD Kecamatan Polokarto, KKG PAI SD Kecamatan Bendosari, KKG PAI SD Kecamatan Baki, KKG PAI SD Kecamatan Tawangsari.

Dalam operasionalnya tiap KKG PAI SD yang membutuhkan pelatihan ini mengirimkan delegasiya untuk mengikuti kegiatan tersebut. Kemudian diharapkan tiap delegasi tersebut akan menularkan atau mensosialisasikan kepada temen-temen guru PAI yang ada di daerahnya yang tergabung dalam KKG PAI SD. Jumlah delegasi yang dikirim disesuaikan kesepakatan antara Jurusan PAI Fakultas Ilmu Tarbiyah dan Keguruan IAIN Surakarta dengan pihak pengurus KKG PAI SD yang membutuhkan pelatihan ini.

b. Program pelatihan PTK. Program ini menempati urutan nomor dua berdasarkan dari pemetaan kebutuhan peningkatan kompetensi guru PAI SD di Kabupaten Sukoharjo. Program ini dibutuhkan oleh lima KKG PAI SD yakni KKG PAI SD Kecamatan Kartasura, KKG PAI SD Kecamatan Mojolaban, KKG PAI SD Kecamatan Grogol, KKG PAI SD Kecamatan Weru, dan KKG PAI SD Kecamatan Sukoharjo. Dalam operasionalnya tiap KKG PAI SD yang membutuhkan pelatihan ini mengirimkan delegasiya untuk 
mengikuti kegiatan tersebut. Kemudian diharapkan tiap delegasi tersebut akan menularkan atau mensosialisasikan kepada temen-temen guru PAI yang ada di daerahnya yang tergabung dalam KKG PAI SD. Jumlah delegasi yang dikirim disesuaikan kesepakatan antara Jurusan PAI Fakultas Ilmu Tarbiyah dan Keguruan IAIN Surakarta dengan pihak pengurus KKG PAI SD yang membutuhkan pelatihan ini.

c. Bimbingan tilawah dan qiroah Al-Qur'an. Program ini menempati urutan nomor tiga berdasarkan dari pemetaan kebutuhan peningkatan kompetensi guru PAI SD di Kabupaten Sukoharjo. Program ini dibutuhkan oleh empat KKG PAI SD yakni KKG PAI SD Kecamatan Sukoharjo, KKG PAI SD Kecamatan Bulu, KKG PAI SD Kecamatan Bendosari, dan KKG PAI SD Kecamatan Tawangsari. Dalam operasionalnya tiap KKG PAI SD yang membutuhkan pelatihan/bimbingan ini mengirimkan delegasiya untuk mengikuti kegiatan tersebut. Kemudian diharapkan tiap delegasi tersebut akan menularkan atau mensosialisasikan kepada temen-temen guru PAI yang ada di daerahnya yang tergabung dalam KKG PAI SD. Jumlah delegasi yang dikirim disesuaikan kesepakatan antara Jurusan PAI Fakultas Ilmu Tarbiyah dan Keguruan IAIN Surakarta dengan pihak pengurus KKG PAI SD yang membutuhkan pelatihan ini.

d. Pelatihan Pembuatan alat peraga atau media pembelajaran. Program ini menempati urutan nomor empat berdasarkan dari pemetaan kebutuhan peningkatan kompetensi guru PAI SD di Kabupaten Sukoharjo. Program ini dibutuhkan oleh tiga KKG PAI SD yakni KKG PAI SD Kecamatan Polokarto, KKG PAI SD Kecamatan Grogol, dan KKG PAI SD Kecamatan Weru. Dalam operasionalnya tiap KKG PAI SD yang membutuhkan pelatihan ini mengirimkan delegasiya untuk mengikuti kegiatan tersebut. Kemudian diharapkan tiap delegasi tersebut akan menularkan atau mensosialisasikan kepada temen-temen guru PAI yang ada di daerahnya yang tergabung dalam KKG PAI SD. Jumlah delegasi yang dikirim disesuaikan kesepakatan antara Jurusan PAI Fakultas Ilmu Tarbiyah dan Keguruan 
IAIN Surakarta dengan pihak pengurus KKG PAI SD yang membutuhkan pelatihan ini.

e. Pelatihan Pembelajaran IT/TIK. Program ini menempati urutan nomor empat berdasarkan dari pemetaan kebutuhan peningkatan kompetensi guru PAI SD di Kabupaten Sukoharjo. Program ini dibutuhkan oleh tiga KKG PAI SD yakni KKG PAI SD Kecamatan Kartasura, KKG PAI SD Kecamatan Sukoharjo, dan KKG PAI SD Kecamatan Baki. Pelatihan Pembelajaran IT/TIK ini menempati prioritas nomor empat sebagaimana pelatihan pembuatan alat peraga atau media pembelajaran karena sama-sama dibutuhkan oleh 3 KKG PAI SD. Dalam operasionalnya tiap KKG PAI SD yang membutuhkan pelatihan ini mengirimkan delegasiya untuk mengikuti kegiatan tersebut. Kemudian diharapkan tiap delegasi tersebut akan menularkan atau mensosialisasikan kepada temen-temen guru PAI yang ada di daerahnya yang tergabung dalam KKG PAI SD. Jumlah delegasi yang dikirim disesuaikan kesepakatan antara Jurusan PAI Fakultas Ilmu Tarbiyah dan Keguruan IAIN Surakarta dengan pihak pengurus KKG PAI SD yang membutuhkan pelatihan ini.

f. Pelatihan pembuatan kisi-kisi dan soal ulangan. Program ini menempati urutan nomor lima berdasarkan dari pemetaan kebutuhan peningkatan kompetensi guru PAI SD di Kabupaten Sukoharjo. Program ini dibutuhkan oleh dua KKG PAI SD yakni KKG PAI SD Kecamatan Polokarto dan KKG PAI SD Kecamatan Mojolaban. Dalam operasionalnya tiap KKG PAI SD yang membutuhkan pelatihan ini mengirimkan delegasiya untuk mengikuti kegiatan tersebut. Kemudian diharapkan tiap delegasi tersebut akan menularkan atau mensosialisasikan kepada temen-temen guru PAI yang ada di daerahnya yang tergabung dalam KKG PAI SD. Jumlah delegasi yang dikirim disesuaikan kesepakatan antara Jurusan PAI Fakultas Ilmu Tarbiyah dan Keguruan IAIN Surakarta dengan pihak pengurus KKG PAI SD yang membutuhkan pelatihan ini. 
g. Pelatihan pembuatan bahan ajar. Program ini menempati urutan nomor enam berdasarkan dari pemetaan kebutuhan peningkatan kompetensi guru PAI SD di Kabupaten Sukoharjo. Program ini dibutuhkan oleh satu KKG PAI SD yakni KKG PAI SD Kecamatan Kartasura. Dalam operasionalnya KKG PAI SD Kecamatan Kartasura yang membutuhkan pelatihan ini mengirimkan delegasiya untuk mengikuti kegiatan tersebut. Kemudian diharapkan delegasi tersebut akan menularkan atau mensosialisasikan kepada temen-temen guru PAI yang ada di daerahnya yang tergabung dalam KKG PAI SD. Jumlah delegasi yang dikirim disesuaikan kesepakatan antara Jurusan PAI Fakultas Ilmu Tarbiyah dan Keguruan IAIN Surakarta dengan pihak pengurus KKG PAI SD yang membutuhkan pelatihan ini.

h. Bintek Kurikulum 2013. Program ini menempati urutan nomor enam berdasarkan dari pemetaan kebutuhan peningkatan kompetensi guru PAI SD di Kabupaten Sukoharjo. Program ini dibutuhkan oleh satu KKG PAI SD yakni KKG PAI SD Kecamatan Baki. Dalam operasionalnya KKG PAI SD Kecamatan Baki yang membutuhkan pelatihan ini mengirimkan delegasiya untuk mengikuti kegiatan tersebut. Kemudian diharapkan delegasi tersebut akan menularkan atau mensosialisasikan kepada temen-temen guru PAI yang ada di daerahnya yang tergabung dalam KKG PAI SD. Jumlah delegasi yang dikirim disesuaikan kesepakatan antara Jurusan PAI Fakultas Ilmu Tarbiyah dan Keguruan IAIN Surakarta dengan pihak pengurus KKG PAI SD yang membutuhkan pelatihan ini.

i. Pelatihan pembuatan administrasi GPAI. Program ini menempati urutan nomor enam berdasarkan dari pemetaan kebutuhan peningkatan kompetensi guru PAI SD di Kabupaten Sukoharjo. Program ini dibutuhkan oleh satu KKG PAI SD yakni KKG PAI SD Kecamatan Gatak. Dalam operasionalnya KKG PAI SD Kecamatan Gatak yang membutuhkan pelatihan ini mengirimkan delegasiya untuk mengikuti kegiatan tersebut. Kemudian diharapkan delegasi tersebut akan menularkan atau mensosialisasikan 
kepada temen-temen guru PAI yang ada di daerahnya yang tergabung dalam KKG PAI SD. Jumlah delegasi yang dikirim disesuaikan kesepakatan antara Jurusan PAI Fakultas Ilmu Tarbiyah dan Keguruan IAIN Surakarta dengan pihak pengurus KKG PAI SD yang membutuhkan pelatihan ini.

j. Pelatihan seni grafi. Program ini menempati urutan nomor enam berdasarkan dari pemetaan kebutuhan peningkatan kompetensi guru PAI SD di Kabupaten Sukoharjo. Program ini dibutuhkan oleh satu KKG PAI SD yakni KKG PAI SD Kecamatan Bendosari. Dalam operasionalnya KKG PAI SD Kecamatan Bendosari yang membutuhkan pelatihan ini mengirimkan delegasiya untuk mengikuti kegiatan tersebut. Kemudian diharapkan delegasi tersebut akan menularkan atau mensosialisasikan kepada temen-temen guru PAI yang ada di daerahnya yang tergabung dalam KKG PAI SD. Jumlah delegasi yang dikirim disesuaikan kesepakatan antara Jurusan PAI Fakultas Ilmu Tarbiyah dan Keguruan IAIN Surakarta dengan pihak pengurus KKG PAI SD yang membutuhkan pelatihan ini.

k. Pelatihan seni macapat islami dan rebana. Program ini menempati urutan nomor enam berdasarkan dari pemetaan kebutuhan peningkatan kompetensi guru PAI SD di Kabupaten Sukoharjo. Program ini dibutuhkan oleh satu KKG PAI SD yakni KKG PAI SD Kecamatan Tawangsari. Dalam operasionalnya KKG PAI SD Kecamatan Tawangsari yang membutuhkan pelatihan ini mengirimkan delegasiya untuk mengikuti kegiatan tersebut. Kemudian diharapkan delegasi tersebut akan menularkan atau mensosialisasikan kepada temen-temen guru PAI yang ada di daerahnya yang tergabung dalam KKG PAI SD. Jumlah delegasi yang dikirim disesuaikan kesepakatan antara Jurusan PAI Fakultas Ilmu Tarbiyah dan Keguruan IAIN Surakarta dengan pihak pengurus KKG PAI SD yang membutuhkan pelatihan ini.

1. Pelatihan pembuatan Prota, Promes, Silabus, RPP, dan Program evaluasi. Program ini menempati urutan nomor enam berdasarkan dari pemetaan kebutuhan peningkatan 
kompetensi guru PAI SD di Kabupaten Sukoharjo. Program ini dibutuhkan oleh satu KKG PAI SD yakni KKG PAI SD Kecamatan Weru. Dalam operasionalnya KKG PAI SD Kecamatan Weru yang membutuhkan pelatihan ini mengirimkan delegasiya untuk mengikuti kegiatan tersebut. Kemudian diharapkan delegasi tersebut akan menularkan atau mensosialisasikan kepada temen-temen guru PAI yang ada di daerahnya yang tergabung dalam KKG PAI SD. Jumlah delegasi yang dikirim disesuaikan kesepakatan antara Jurusan PAI Fakultas Ilmu Tarbiyah dan Keguruan IAIN Surakarta dengan pihak pengurus KKG PAI SD yang membutuhkan pelatihan ini.

Pengadaan program pengabdian yang didasarkan atas urutan prioritas kebutuhan pengembangan kompetensi guru PAI SD ini disesuaikan dengan kemampuan yang dimiliki oleh Jurusan PAI Fakultas Ilmu Tarbiyah dan Keguruan IAIN Surakarta. Untuk lebih mudah dalam menggambarkan desain program pengabdian dosen Jurusan PAI Fakultas Ilmu Tarbiyah dan Keguruan IAIN Surakarta yang didasarkan atas urutan prioritas kebutuhan pengembangan kompetensi guru PAI SD di Kabupaten Sukoharjo dapat dilihat di bawah ini:

Tabel 2.

Urutan Prioritas Kebutuhan Peningkatan Kompetensi Guru PAI SD di Kabupaten Sukoharjo

\begin{tabular}{|c|c|c|}
\hline $\begin{array}{c}\text { Urutan } \\
\text { Prioritas }\end{array}$ & Program kegiatan & Nama KKG PAI SD \\
\hline 1. & $\begin{array}{l}\text { Pelatihan strategi/metode } \\
\text { pembelajaran }\end{array}$ & $\begin{array}{l}\text { KKG PAI SD Kec. Nguter } \\
\text { KKG PAI SD Kec. Gatak } \\
\text { KKG PAI SD Kec. Bulu } \\
\text { KKG PAI SD Kec. Polokarto } \\
\text { KKG PAI SD Kec. Bendosari } \\
\text { KKG PAI SD Kec. Baki } \\
\text { KKG PAI SD Kec. Tawangsari }\end{array}$ \\
\hline
\end{tabular}


KKG PAI SD Kec. Kartasura

KKG PAI SD Kec. Mojolaban

2

Pelatihan penyusunan PTK KKG PAI SD Kec. Grogol

KKG PAI SD Kec. Weru

KKG PAI SD Kec. Sukoharjo

KKG PAI SD Kec. Sukoharjo

3.

Bimbingan tilawah dan KKG PAI SD Kec. Bulu qiroah Al-Qur'an

KKG PAI SD Kec. Bendosari

KKG PAI SD Kec. Tawangsari

Pelatihan Pembuatan KKG PAI SD Kec. Polokarto,

4. alat peraga atau media pembelajaran

KKG PAI SD Kec. Grogol

KKG PAI SD Kec. Weru

KKG PAI SD Kec. Kartasura

Pelatihan Pembelajaran IT/ TIK

KKG PAI SD Kec. Sukoharjo

KKG PAI SD Kec. Baki

Pelatihan pembuatan kisi- KKG PAI SD Kec. Polokarto kisi dan soal ulangan KKG PAI SD Kec.Mojolaban

Pelatihan pembuatan

bahan ajar

KKG PAI SD Kec. Kartasura

Bintek Kurikulum 2013 KKG PAI SD Kec. Baki

Pelatihan pembuatan

administrasi GPAI

KKG PAI SD Kec. Gatak

6 Pelatihan seni grafi

KKG PAI SD Kec. Bendosari

Pelatihan seni macapat islami dan rebana

KKG PAI SD Kec. Tawangsari

Pelatihan pembuatan Prota,

Promes, Silabus, RPP, dan KKG PAI SD Kec. Weru Program evaluasi 


\section{Kesimpulan}

Berdasarkan uraian-uraian di atas, maka dapatlah diambil beberapa kesimpulan yaitu, 1) Hasil pemetaan kebutuhan pengembangan kompetensi guru PAI SD di Kabupaten Sukoharjo yang disampaikan oleh pengurus KKG PAI SD di dua belas kecamatan yakni pelatihan strategi/metode pembelajaran, pelatihan penyusunan PTK, bimbingan tilawah dan qiroah al-Qur'an, pelatihan pembuatan alat peraga atau media Pembelajaran, Pelatihan pembelajaran IT/ TIK, pelatihan pembuatan kisi-kisi dan soal ulangan, Pelatihan pembuatan bahan ajar, bintek kurikulum 2013, pelatihan pembuatan administrasi GPAI, pelatihan seni grafi, pelatihan seni macapat islami dan rebana, pelatihan pembuatan Prota, Promes, Silabus, RPP, dan program evaluasi. 2). Desain program pengabdian dosen Jurusan PAI Fakultas Ilmu Tarbiyah dan Keguruan IAIN Surakarta meliputi: a) Desain pengabdian dosen Jurusan PAI dilakukan dengan fokus pada kebutuhan pengembangan kompetensi guru PAI SD di satu kecamatan di Kabupaten Sukoharjo dan kemudian bisa dilanjutkan ke kecamatan lainnya. b) Desain pengabdian dosen Jurusan PAI sesuai urutan prioritas kebutuhan pengembangan kompetensi guru PAI SD di Kabupaten Sukoharjo.

\section{Daftar Pustaka}

Achmadi. 1992. Islam paradigma Ilmu Pendidikan. Yogyakarta : Aditya Media.

Aqib, Zainal. 2002. Profesionalisme Guru Dalam Pembelajaran. Surabaya: Cendikia.

Ardy, Novan. 2012. Pendidikan Karakter Barbasis Iman dan Taqwa. Yogyakarta: Teras.

Arwildayanto. 2012. Manajemen Sumber Daya Manusia Perguruan Tinggi, Pendekatan Budaya Kerja Dosen professional. Gorontalo: Ideas Publising.

Hidayah, Sofi Fitria dan Tairas. 2013. "Perbedaan Tingkat Teacher Efficacy ditinjau dari Status Sertifikasi pada Guru Sekolah Menengah Atas di Tuban". Jurnal Psikologi Pendidikan dan Perkembangan, Vol. 2, No. 01. 
Margono. 2009. Metode Penelitian Pendidikan. Jakarta: Pustaka Umum.

Miles, Matthew B. and A. Michael Huberman. 1992. Analisis Data Kualitatif, Terj. Tjetjep Rohandi Raihidi. Jakarta: UI Press.

Muhibbin Syah. 2000. Psikologi Pendidikan dengan Pendekatan Baru. Bandung: PT Remaja Rosdakarya.

Mulyasa. 2004. Standar Kompetensi dan Sertifikasi Guru. Bandung: PT. Remaja Rosdakarya.

Musfah, Jejen. 2012. Peningkatan Kompetensi Guru Melalui Pelatihan Sumber Belajar Teori dan Praktik. Jakarta: Kencana Prenada Media Group.

Noorsyam, Muhammad. 1986. Filsafat Pendidikan dan Dasar Filsafat Kependidikan Pancasila. Surabaya: Usaha Nasional.

Rusman. 2013. Model-Model Pembelajaran: Mengembangkan Profesionalisme Guru. Jakarta: Rajawali Pers.

Rusyan, A. Tabrani, dkk. 2000. Upaya Meningkatkan Budaya Kinerja Guru Sekolah Dasar. Jakarta: PT. Nusantara Lestari Ceria Pertama.

Sarimaya, Farida. 2008. Sertifikasi Guru, Apa, Mengapa dan Bagaimana?. Bandung: Yrama Widya.

Usman, Moh. Uzer. 2001. Menjadi Guru Profesional. Bandung: PT. Remaja Rosdakarya.

Wahyudin, Din. 1995. Monitoring dan Evaluasi Petunjuk bagi Para Pelaksana. Jakarta: PEQIP. 